Journal of Environmental Science and Sustainable Development

$12-31-2018$

\title{
Optimization Of Transportation of Municipal Solid Waste from Resource to Intermediate Treatment Facility with Nearest Neighbour Method (Study on six Sub Sub District in DKI Jakarta Province)
}

Fahmi Hermawan

School of Environmental Science, Universitas Indonesia, Jakarta 10430, abaykmy@gmail.com

Follow this and additional works at: https://scholarhub.ui.ac.id/jessd

Part of the Environmental Studies Commons

\section{Recommended Citation}

Hermawan, Fahmi (2018). Optimization Of Transportation of Municipal Solid Waste from Resource to Intermediate Treatment Facility with Nearest Neighbour Method (Study on six Sub Sub District in DKI Jakarta Province). Journal of Environmental Science and Sustainable Development, 1(1), 86-99. Available at: https://doi.org/10.7454/jessd.v1i1.21

This Review Article is brought to you for free and open access by the School of Environmental Science at UI Scholars Hub. It has been accepted for inclusion in Journal of Environmental Science and Sustainable Development by an authorized editor of UI Scholars Hub. 


\title{
OPTIMIZATION OF TRANSPORTATION OF MUNICIPAL SOLID WASTE FROM SOURCE TO INTERMEDIATE TREATMENT FACILITY USING THE NEAREST NEIGHBOR METHOD (STUDY ON SIX SUB-DISTRICTS IN DKI JAKARTA PROVINCE)
}

\author{
Fahmi Hermawan* \\ School of Environmental Science, Universitas Indonesia, Central Jakarta 10430, Indonesia \\ *Corresponding author: e-mail: abaykmy@gmail.com
}

(Received: 20 November 2018; Accepted: 27 December 2018; Published: 31 December 2018)

\begin{abstract}
Population growth is always accompanied by an increase in waste generation. The issue of the increasing volume of waste becomes crucial if it is not balanced through proper handling efforts. The Provincial Government of DKI Jakarta through the Environment Agency of DKI Jakarta Province seeks to address the waste problem by constructing alternative facilities in the city's waste processing facilities. The processing facilities referred to here are the Waste Power Generation or Intermediate Treatment Facility. The operational sustainability and the production output of the facility are influenced by the amount of waste supply as its raw material and are also influenced by the optimization of the transportation route of waste to the facility. The purpose of this research was to develop a model that can optimize the transportation route of waste from the source to the Intermediate Treatment Facility. The nearest neighbor method was to devise a truck travel route to serve the temporary waste shelter closest to the last visited location. The result of this research was obtained by route and trip that has new implications on garbage transportation which more optimize from the side of transport capacity, travel time, distance, and decrease from previous condition to the requirement of garbage truck procurement equal to $39.16 \%$, fuel cost of $35.64 \%$, human resources salary of $39.16 \%$, and $35.64 \%$ reduction in greenhouse gas emissions. The implementation of the new routes and trips has a very positive impact in terms of the economic viewpoint to save operational costs, reduce the social impacts of delays in transporting waste from the sources, and reduce emissions from transportation operations.
\end{abstract}

Keywords: DKI Jakarta; intermediate treatment facility; municipal solid waste (MSW); nearest neighbor; route

\section{Introduction}

The increasing population growth coupled with an increase in the needs of people will lead to various pressures and environmental degradation (Utomo, Sutriyono, \& Rizal, 2014). However, the rapid and constant growth of the population can also lead to an increase in waste production, which has an important social, economic, and environmental impact (Das \& Bhattacharyya, 2015). The high volume of waste generated by both industry and society is a common problem encountered in almost all cities, especially in big cities such as DKI Jakarta. Good waste management is the need of each region to make a clean and healthy 
environment, and in achieving these targets an effective waste transportation distribution system is needed in order to reduce costs so that it can be used for other needs.

The environmental sustainability of the entire waste management systems is an issue that is currently being evaluated by researchers across the world (Rigamonti, Sterpi, \& Grosso, 2016), particularly in terms of their energy consumption and their return performances (Tomić \& Schneider, 2017). Municipal solid waste (MSW) management system may be subdivided into the three following phases: collection, transportation, and waste treatment (thermal, biological, and mechanical pretreatments and landfilling). The effectiveness, from an environmental point of view, of MSW management systems is strongly dependent on the level of separate collection; a limited disposal in a landfill will result in small amounts of the released greenhouse gases (Calabrò, 2009; Calabrò, Gori, \& Lubello, 2015). However, most of the research attention appears to be turned toward either the final steps of the chain, namely waste treatments, or the initial ones, i.e., the collection. Nabavi-Pelesaraei, Bayat, Hosseinzadeh-Bandbafha, Afrasyabi, \& Chau (2017) indicated the attention on the energy and environmental performances of incineration and landfilling of MSW; Widomski, Gleń, \& Łagód (2017) specifically considered the sustainability of landfilling processes; Rimaityte, Denafas, Martuzevicius, \& Kavaliauskas (2010) analyzed the sustainability of the solid waste incineration as the crucial phase for defining optimized waste management systems. Other authors, e.g., Chi, Dong, Tang, Huang, \& Ni (2015), considered the collection of MSW from a life-cycle-assessment point of view, particularly analyzing the importance of a sourceseparated collection for the entire total environmental performance of an MSW system. The energy and environmental impact of MSW recycling has been investigated, by virtue of its evident importance in the life cycle perspective of the waste management systems (NabaviPelesaraei, Bayat, Hosseinzadeh-Bandbafha, Afrasyabi, \& Berrada, 2017).

The Provincial Government of DKI Jakarta through the Environmental Agency of DKI Jakarta Province seeks to address the problem of waste by constructing alternative facilities in the city's waste treatment facilities. The processing facilities referred to here are the Waste Power Plants or the Intermediate Treatment Facility (ITF). Based on the 2012-2032 Provincial Waste Management Masterplan, the facility will be constructed in four different locations in Jakarta, including Sunter, Marunda, Cakung, and Duri Kosambi. If alternative facilities are constructed, it is expected that they would be able to reduce the burden of garbage accumulation in the final disposal at Bantargebang (Surjandari, Hidayatno, \& Supriatna, 2009).

Based on data from the Environmental Agency of DKI Jakarta Province, in 2017, the average amount of waste from DKI Jakarta that goes to the Integrated Waste Treatment Plant at Bantargebang is 6,896.95 tons/day. Currently, Bantargebang is the only Final Disposal Site of DKI Jakarta Provincial Government located in Bekasi City, West Java Province. The amount of waste is large enough, Bantargebang forward is expected to decrease the carrying capacity and capacity. This will also have a direct impact on the disruption of waste handling pattern in DKI Jakarta if it is not immediately addressed by the existence of an alternative pattern of good waste management and an alternative place of waste processing at other locations within the city.

The operational sustainability and the production output from the ITF are influenced by the amount of supply of waste (feeding) as the primary raw material. A problem in any one of 
these parameters supporting the waste supply will disrupt the operation and production of this facility. The amount of waste supply as mentioned above is also influenced by the pattern of truck transport that brings waste from the waste source to the ITF.

Distribution issues involve several key considerations such as vehicle routes, vehicle fleets, and vehicle scheduling (Bodin, Golden, Assad, \& Ball (1983) in Fitria, Susanty, \& Suprayogi (2009)). Factors that potentially affect the transportation system of this waste transport include the level of congestion, distance, workers (number and performance), and the number of temporary disposal sites (TPS) of garbage. This problem then becomes the vehicle routing problem (VRP), which has several types of objectives related to minimizing the cost of distribution (minimizing the number of vehicles, vehicle travel time, vehicle mileage, and other purposes according to the characteristics of the problem) (Fitria et al., 2009).

Garbage is a waste product of human and animal activities in the form of solids; it is not needed and no longer useful (Tchnobanoglous, 1993). Chandra (2007) states that waste does not occur by itself, it is from all useless human activities.

The Law of the Republic of Indonesia, Number 18 Year 2008, on Waste Management states that the source of waste is the origin of waste generation. The source of waste consists of waste generating sources such as shops (commercial or trade activities), households, street sweeping, markets, parks, and other public places and other sources such as the type of waste generated from industrial activities and trash produced by daily human activities, potentially containing B3 waste such as oil residue, battery residue, remnants of car brake fluid, remaining plant biocides, and residual mosquito repellents (Damanhuri, 2006).

Urban waste management strategies should be aimed at reducing waste at the source, and this is done to reduce dependence on the increasingly land (Kholil, Eriyatno, Sutjahyo, \& Soekarto, 2009). The issue of handling waste in big cities in Indonesia is an urban problem that till today has become a challenge for the local government. The rapid activity accompanied by the growth of cities and people in big cities has resulted in an increase in the waste problem accompanied by its quantity (Damanhuri, 2006).

Azwar (1990) suggests that waste processing is a treatment activity against waste that aims to reduce or eliminate problems related to the environment. Garbage processing problems are closely associated with the technology used. Surjandari et al. (2009) stated that based on analysis results of system dynamics and benefit-cost ratio $(\mathrm{B} / \mathrm{C})$ and the analytic hierarchy process, waste processing in DKI Jakarta must be done continuously by $3 \mathrm{R}$ and then the waste must be processed in the incinerator.

Waste management in principle is the responsibility of the local government (CointreauLevine, 1994). There is a tendency for inefficiency in waste transport by the public sector (local government) (Chakrabarti, Majumder, \& Chakrabarti, 2009). This inefficiency generally comes from the inefficiency of labor usage in the process of collecting and transporting waste in developing countries (Cointreau-Levine, 1994).

Transportation of waste is influenced by accessibility or travel time, the frequency of transportation, the pattern of transportation, and the level of transportation services; thus, waste management is one of the services to the public regarding the waste that it produces while maintaining and improving the health status (Hartanto, 2006). The problem of 
transporting rubbish consists of transport routes to pick up garbage within a certain timeframe to minimize travel costs (Buhrkal, Larsen, \& Ropke, 2012).

This waste transport system can be modeled as a variant of the VRP with multiple routes and ITF (Fitria et al., 2009). The model of this trip routes can be determined based on the estimation of the effective time required for trucks to carry out the process of transporting waste from the TPS to the final disposal site.

The implementation of waste transport process can be modeled as a variant of the VRP with multiple routes and ITF. Distribution issues involve several key indicators, including vehicle fleets, vehicle routes, and vehicle scheduling (Bodin et al., 1983). The VRP issues are defined as route determination issues with minimum cost of a customer to a scattered customer with a total varying demand (Bräysy, 2001).

Garbage is a major issue in the urban environment. Waste is material that has no value or value for ordinary or primary purpose in the use of damaged or defective goods (Astriani, 2009). Waste processing is a treatment effort (treatment that aims to eliminate or reduce problems that would impact the environment (Azwar, 1990).

Garbage processing problems are closely related to the technology used. Based on the results of multidimensional scaling (MDS) analysis, garbage processing is a type of integrated community-based waste processing that involves composting and recycling paper (Yogiesti, Hariyani, \& Sutikno, 2012). Construction of Waste To Energy (WTE/ITF) facility aims to reduce garbage by $80 \%-90 \%$ of the total waste capacity at each WTE/ITF (Ministry of Energy and Mineral Resources of the Republic of Indonesia, 2015). There are several advantages and disadvantages of the construction and operation of the ITF as intended (Miller \& Spoolman, 2016). The purpose of this research was to develop a model that can optimize the transportation route of waste from the source to the Intermediate Treatment Facility. In the future this research still needs to be further developed, so that it can discuss aspects as a whole, especially with respect to some of the supporting variables.

\section{Methods}

The problem of determining the route of the garbage truck in this study is modeled on the Vehicle Routing Problem with Multi Trips and ITF(VRPMTITF) (Fitria et al., 2009) and then finalized using the nearest neighbor method, which after its completion would show the effectiveness of the route formed.

The nearest neighbor method is applied to determine a solution for the problem of defining the route by finding the closest distance to the destination location (Abadi, Susanty, $\&$ Adianto, 2014). The fundamental requirement of this method is establishing the transportation routes by determining the consumers who are located nearby from the initial location. The nearest neighbor heuristic method is a simple constructive procedure that constructs an iterative Hamiltonian path by connecting a temporary disposal site (TPS) inserted into previously unrelated and nearby iterations. According to Mardiani, Yossyafra, \& Gunawan (2013), routing used in trash transport based on Pop, Sitar, Zelina, Lupşe, \& Chira (2011) is described as follows: garbage transport will find the shortest route always from the depot to the nearest temporary disposal site to pick up waste generation, every TPS is visited only once, from TPS the garbage transport will directly go to the final disposal site or the ITF by finding the shortest route, after arriving at the final disposal site or the ITF, the garbage 
transport can return to the nearest temporary disposal site with a record of sufficient time of operation, if not enough, then the garbage transport will return to the vehicle depot by finding the shortest route, traveling from depot to return to depot is known as one route, the route will be completed when all the TPS have been completed.

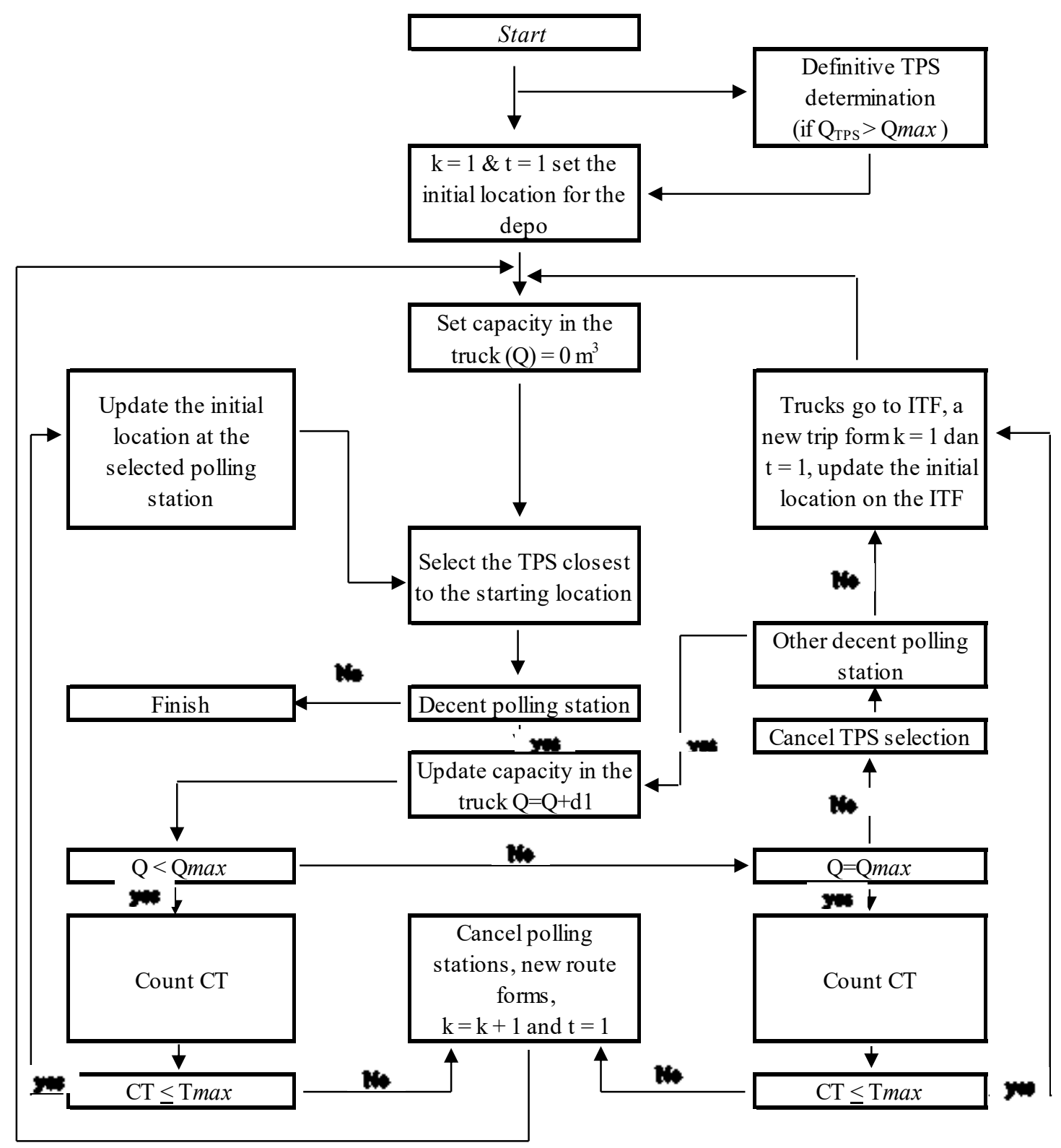

Figure 1. Flow chart of the nearest neighbor method (insertion of definitive TPS)

The problem analysis flow using the nearest neighbor method (Fatharani, 2013) is as follows: Stage 1 determines the demand or capacity of the vehicle $(\mathrm{Q})=0 \mathrm{~m} 3$, the first route $(\mathrm{k}=1)$ there is the first trip $(\mathrm{t}=1)$, the initial location at the depot $(0)$. Stage 2 assigns customers with destinations that have the closest distance to the original location; if all customers have been selected, continue to stage 11. Stage 3 calculates the demand or capacity of the vehicle $(\mathrm{Q}=\mathrm{Q}+$ in). In Stage 4, if $\mathrm{Q}<$ the maximum capacity of the vehicle ( $\mathrm{Q} \max$ ), proceed to step 5. If $\mathrm{Q}=\mathrm{Q} \max$, continue to step 7. If $\mathrm{Q}>\mathrm{Q} \max$, proceed to step 8. Stage 5 calculates the total route completion time $(\mathrm{CT})$ according to the equation. If $\mathrm{CT}<$ Maximum 
vehicle time (T max), proceed to step 6. If CT> T max, proceed to stage 10. Stage 6 prepares the selected customer as the start (place or location) early, then repeat step 2. Stage 7calculates $\mathrm{CT}$. If $\mathrm{CT}<\mathrm{T} \max$, go to step 9. If $\mathrm{CT}>\mathrm{T}$ max, proceed to stage 10 . Stage 8 rejects (cancels) the last customer, and then selects another customer that has not been selected closest to the original location and proceed to stage 3. If all customers are not eligible, continue to stage 9. Stage 9 is the truck to TPA/ITF(X) to discharge (unloading) the load. Specify a new trip, with $X$ as the initial start, then repeat step 1 , where $(t=t+1)$. Stage 10 rejects (cancels) the last customer; then, return to stage 1 to form a new route (next route) $(\mathrm{k}=\mathrm{k}+1)$. In Stage 11, all customers have been served, and then the route selection ends. The population and sample for this research is the location of the waste temporary disposal site (TPS) in six sub-districts in DKI Jakarta Province (Kemayoran, Sawah Besar, Tanjung Priok, Pademangan, Tamansari, and Tambora), totaling 192 locations of TPS. The study was conductedfrom January to April 2018, based on the selection of subjects and research objects, namely, the sub-district near the location of the planned construction of waste processing facilities in Sunter, North Jakarta. The observation was carried out by conducting a direct survey on the field and a desk study based on relevant literature. The research variables were the optimization model of waste transportation (truck capacity, distance, speed, time, route, and trip), waste transportation routes, and the fulfillment of the needs of waste at the Sunter garbage processing facility in North Jakarta.

\section{Results and Discussion}

The model for determining the route of garbage trucks in this research with the following limits/constraints each route serving the TPS starts from the trucking pool (in this case, each Office of the Environment Department of the City of Administration), each TPS is served only once by one truck, the amount of TPS capacity transported on a trip in a route does not exceed the maximum capacity of the truck, truck to the ITF(in this case the ITFSunter) to dispose of the trash and empty the truck, the time required to complete one route, not exceeding the maximum time determined by the DKI Jakarta Environmental Office, routes can be started from the ITF(in this case the ITFSunter) if the maximum time determined by Environmental Agency of DKI Jakarta is still sufficient, each route is terminated at the Pool of the truck (in this case each Office of the Environment Department of the City of Administration) is empty (not carrying garbage).

The following assumptions were used in this research: the garbage collector used is the temporary disposal site spread in the sub-districts Kemayoran, Sawah Besar, Tanjung Priok, Pademangan, Tambora, and Tamansari; the pattern of garbage transport is the direct door transportation pattern using truckloads of trucks with a capacity of 6 tons; the volume or capacity of garbage at each Temporary Disposal Site is always full; congestion is ignored and the truck speed is constant at $40 \mathrm{~km} / \mathrm{h}$; the time provided to complete the waste transport process is $4 \mathrm{~h}$; and the service time at the Temporary Disposal Site (loading) per 1 ton is 5 min, while the service time at the ITF(unloading) per 1 ton is $2 \mathrm{~min}$. 


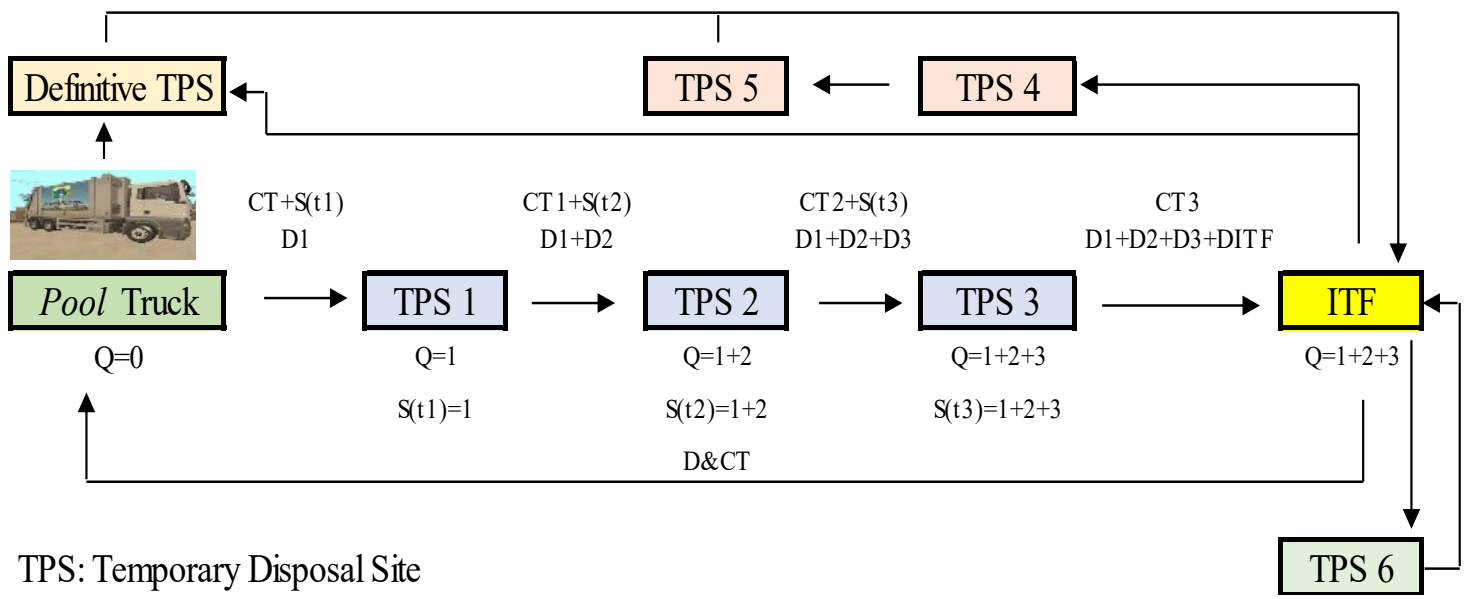

Figure 2. Illustration of the VRPMTITF model using the nearest neighbor method and with definitive TPS

According to Table 1 and Table 2, the results obtained from the development of the VRPMTITF model that are solved by the nearest neighbor method are described below.

For Kemayoran and Sawah Besar sub-districts, the service is to 66 TPS locations with 15 routes; the trash load capacity of all routes is 250.88 tons, the travel time for all routes is $3.085,38 \mathrm{~min}$, the travel distance of all routes is $865.93 \mathrm{~km}$, the need for garbage transport trucks is 46 units, the budget requirements (cost) for fuel amount to 4.41 billion/year (IDR), the budget requirements (cost) for employee salaries amount to 6.76 billion/year (IDR), and the greenhouse gas emissions generated are 1.9 million $\mathrm{kg} /$ year $\mathrm{CO}_{2}$ eq.

For Tanjung, Priok, and Pademangan sub-districts, the service is to 59 TPS locations with 18 routes; the trash load capacity of all routes is 397.05 tons, the travel time for all routes is $3.923,17 \mathrm{~min}$, the travel distance of all routes is $787.29 \mathrm{~km}$, the need for garbage transport trucks is 69 units, the budget requirements (cost) for fuel amount to 6.61 billion/year (IDR), the budget requirements (cost) for employee salaries amount to 6.76 billion/year (IDR), and the greenhouse gas emissions generated are 1.9 million $\mathrm{kg} /$ year $\mathrm{CO}_{2}$ eq.

For Tambora and Tamansari sub-districts, the service is to 67 TPS locations with 12 routes; the trash load capacity of all routes is 185.64 tons, the travel time for all routes is $2.526,70 \mathrm{~min}$, the travel distance of all routes is $817 \mathrm{~km}$, the need for garbage transport trucks is 33 units, the budget requirements (cost) for fuel amount to 3.16 billion/year (IDR), the budget requirements (cost) for employee salaries amount to 4.85 billion/year (IDR), and the greenhouse gas emissions generated are 1.37 million $\mathrm{kg} /$ year $\mathrm{CO}_{2}$ eq.

The development of the VRPMTITF model was validated by comparing the results of the calculation analysis of the number of garbage trucks needed, the fuel (cost) budget requirements, the HR salary costs (costs), and the GHG emissions. If the results of the calculation analysis are higher, then recalculation was carried out again. Based on Table 1 and Table 2, it was found that the existing conditions were greater than the results of the calculation analysis, and hence, the results of the calculation analysis of the development of the VRPMTITF model completed using the nearest neighbor method were considered to be valid. 
Table 1. Matrix of development analysis results of the VRPMTITF model using the nearest neighbor method (for truck needs and fuel cost)

\begin{tabular}{|l|r|r|r|r|r|r|r|r|r|}
\hline \multirow{2}{*}{$\begin{array}{c}\text { Sub- } \\
\text { District }\end{array}$} & \multicolumn{4}{|c|}{ Total } & \multicolumn{2}{|c|}{ Truck Needs } & \multicolumn{2}{|c|}{ Fuel Cost } \\
\cline { 2 - 10 } & TPS & \multirow{2}{*}{ Route } & Capacity & $\begin{array}{c}\text { Travel } \\
\text { Time }\end{array}$ & $\begin{array}{c}\text { Travel } \\
\text { Distance }\end{array}$ & Exist & Result & Exist & Result \\
\cline { 2 - 11 } & (ton) & $(\mathrm{min})$ & $(\mathrm{km})$ & \multicolumn{2}{|c|}{ (unit) } & \multicolumn{2}{|c|}{$\begin{array}{c}\text { (Billion } \\
\text { IDR/year) }\end{array}$} \\
\hline $\begin{array}{l}\text { Kemayoran } \\
\text { \& Sawah } \\
\text { Besar }\end{array}$ & 66 & 15 & 250,88 & $3.085,38$ & 865,83 & 75 & 46 & 6,75 & 4,41 \\
\hline $\begin{array}{l}\text { Tanjung, } \\
\text { Priok, \& } \\
\text { Pademangan }\end{array}$ & 59 & 18 & 397,05 & $3.923,17$ & 787,29 & 98 & 69 & 8,87 & 6,61 \\
\hline $\begin{array}{l}\text { Tambora \& } \\
\text { Tamansari }\end{array}$ & 67 & 12 & 185,64 & $2.526,70$ & 817 & 65 & 33 & 5,94 & 3,16 \\
\hline
\end{tabular}

Table 2. Matrix of development analysis results of the VRPMTITF model using the nearest neighbor method (for employee salary and green house gas)

\begin{tabular}{|c|c|c|c|c|c|c|c|c|c|}
\hline \multirow{3}{*}{$\begin{array}{c}\text { Sub- } \\
\text { District }\end{array}$} & \multicolumn{5}{|c|}{ Total } & \multicolumn{2}{|c|}{$\begin{array}{c}\text { Employee } \\
\text { Salary }\end{array}$} & \multicolumn{2}{|c|}{$\begin{array}{l}\text { Green House } \\
\text { Gas }\left(\mathrm{CO}_{2} \mathrm{eq}\right)\end{array}$} \\
\hline & TPS & Doutt & Capacity & $\begin{array}{l}\text { Travel } \\
\text { Time }\end{array}$ & $\begin{array}{c}\text { Travel } \\
\text { Distance }\end{array}$ & Exist & Result & Exist & Result \\
\hline & (unit) & Koute & (ton) & $(\min )$ & $(\mathrm{km})$ & \multicolumn{2}{|c|}{$\begin{array}{c}\text { (Billion } \\
\text { IDR/year) }\end{array}$} & \multicolumn{2}{|c|}{$\begin{array}{l}\text { (Million } \\
\text { kg/year) }\end{array}$} \\
\hline $\begin{array}{l}\text { Kemayoran } \\
\& \quad \text { Sawah } \\
\text { Besar }\end{array}$ & 66 & 15 & 250,88 & $3.085,38$ & 865,83 & 11,03 & 6,76 & 2,92 & 1,9 \\
\hline $\begin{array}{l}\text { Tanjung, } \\
\text { Priok, \& } \\
\text { Pademangan }\end{array}$ & 59 & 18 & 397,05 & $3.923,17$ & 787,29 & 14,41 & 10,14 & 3,83 & 2,86 \\
\hline $\begin{array}{l}\text { Tambora \& } \\
\text { Tamansari }\end{array}$ & 67 & 12 & 185,64 & $2.526,70$ & 817 & 9,56 & 4,85 & 2,57 & 1,37 \\
\hline
\end{tabular}

Based on Table 1 and Table 2, after further analysis, there was a saving/reduction of difference in the results of the calculation analysis compared with the existing conditions in each sub-district cluster, as described below.

For Kemayoran and Sawah Besar sub-districts, the savings on truck procurement needs are $38.67 \%$, the savings on fuel budget requirement are $34.67 \%$, the savings on employee salary budget requirements are $38.71 \%$, and the greenhouse gas emission reduction is $34.93 \%$.

For Tanjung, Priok, and Pademangan sub-districts, the savings on truck procurement needs are $29.59 \%$, the savings on fuel budget requirement are $25.48 \%$, the savings on employee salary budget requirements are $29.63 \%$, and the greenhouse gas emission reduction is $25.33 \%$. For Tambora and Tamansari sub-districts, the savings on truck procurement needs are $49.23 \%$, the savings on fuel budget requirement are $46.80 \%$, the savings on employee salary budget requirements are $49.27 \%$, and the greenhouse gas emission reduction is $46.69 \%$. Overall average savings or decreases in the six sub-districts under the existing 
conditions are as follows: the need for procurement of garbage truck savings is $37.82 \%$, the need for fuel budget savings is $34.23 \%$, the budget requirement for employee salaries savings is $37.86 \%$, and he savings to reduce greenhouse gas emissions are $34.23 \%$.

The more waste in a temporary disposal site and the longer the waste in the temporary disposal site is not transported to a dumping place (ITF), the more it will cause social and environmental impacts. The route obtained from the analysis of this model has the potential to transport waste from the temporary disposal site faster, thereby reducing the accumulation of waste that occurs at the temporary disposal site. Due to the rapid transport of waste from the temporary disposal site, it has the potential to reduce the environmental impacts that arise. The impacts that are caused are odor, dirtiness, vectors of diseases, flies, and slums, so that efforts to reduce environmental impacts are in line with efforts to reduce social conflicts that have the potential to occur around the temporary disposal site areas, such as closure of polling stations, diseases, community conflicts with local government apparatus, and conflict between communities. This will also affect economic activities in the communities around the temporary disposal site, so that the implementation of this model can also contribute well to the local government to help sustainable development in the waste management sector in the community.

Waste that is not managed properly will form a very good place for some disease-carrying vectors such as flies, mosquitoes, rats, and cockroaches that can multiply rapidly, thereby directly or indirectly interfering with health. The conditions experienced by the community around the polling stations against illness or health caused by the presence of temporary disposal site, with the accumulation of waste and too long not immediately transported to the landfill is a source of disease. Till date, the community around a temporary disposal site has felt that their health is impaired and there are inherited disease factors experienced by some people. The existence of animals is due to the presence of waste decay that can invite flies, mosquitoes, cockroaches, rats, and various other types of disease-causing organisms. Decomposition often even occurs protracted, resulting in the formation of decaying liquid that can interfere with the environmental health of the community.

Climate and rainfall also affect air pollution caused by stagnant rainwater in polling stations, so that the accumulated waste due to delays (too long waiting) that is transported to the landfill becomes rotten and the community is disturbed by the smell when the wind blows. Regarding water pollution around the temporary disposal site location, the community assessment showed that there is impairment in groundwater quality (smelly and discolored) around the temporary disposal site due to the absence of most of the sewerage or garbage collection tanks, so that water flowed to the water bodies and the land around the temporary disposal site. However, the community has other perceptions of the location of the temporary disposal site, namely, that the existence of the temporary disposal site will have an impact on the opening of jobs around the temporary disposal site (e.g., garbage banks, 3R, composting, stall, collectors, etc.).

Community behavior toward waste management is also important for a discussion. Based on the increasing volume of waste over time along with the growth of population in a region, this proves that population growth is not in line with its behavior toward handling waste. Although the community currently does not fully care about waste, the majority still views 
waste as something that is not valuable, useless, and unprofitable, and thus there is no effort to manage or process the waste.

The construction of waste processing facilities equipped with advanced technology and modernity becomes meaningless if it is not supported by the behavior of the community and does not fully guarantee that it will change the behavior pattern of the community toward the waste itself. It is necessary to gradually and intensely carry out activities aimed at reminding the community of their role in the management and processing of waste. The implementation of these activities can be carried out by anyone from three primary elements, namely, the government, the private sector, and the community itself.

Theoretical reflection in analyzing the problem of the researcher uses the theory of dependency principle. The concept of dependence states that an event is strongly influenced by other events. The process of dependence in this study is highly emphasized on the efficiency and effectiveness of the results of a process, so it is very useful for all parties involved. Dependency theoretical reflection in this study can be seen by the savings in operational costs of transporting waste (fuel costs, employee salary costs, and the cost of procuring garbage trucks) from each source to the waste treatment plant and reducing emissions that can damage the environment.

In general, collection and transportation are the most important and expensive aspect of the process because of the labor-intensity of the work and the massive use of vehicles in the collection and transportation process (Amponsah \& Salhi, 2004). An integrated waste management system can improve the vehicle routing, dispatching, maintenance, and management (Sahoo, Kim, Kim, Kraas, \& Popov, 2005; Ionescu \& Stefani, 2014; Li, Zhang, Liu, Meng, \& Du, 2014; Rabbani, Sadri, \& Rafiei, 2014; Xu, Li, Ou, \& Wu, 2015), and in this paper, to improve the road compactness and workload balancing, a scheme is developed for MSW collection and transportation, i.e., an optimization scheme is needed to reduce waste collection and transportation route length. Depending on the complexity of the problem and different waste characteristics, different types of vehicles are used for collection and transportation (Wy, Kim, \& Kim, 2013).

\section{Conclusion}

The development of the model in this research involves the development of the Vehicle Routing Problem with Multiple Trips and ITF(VRPMTITF) model, which is a simple mathematical model of the formation of waste transport routes that are made aiming to shorten the distance of garbage trucks in the operations of waste transport services. The development of the model was completed using the nearest neighbor method, which is the truck serving the temporary disposal site closest to the last location visited. The development of this model results in effective and efficient waste transport operations in waste transport capacity, travel time, travel distance, and costs incurred.

The establishment of a garbage transport route based on the results of the analysis of the development of the VRPMTITF model that was completed using the nearest neighbor method resulted in an effective and efficient garbage transport truck travel route by reducing service time, mileage, transportation operating costs, and greenhouse gas emissions generated, thereby impacting economic, social, and environmental aspects. The amount of garbage from the six sub-districts in DKI Jakarta Province, which was analyzed by 
developing the VRPMTITF model and completed using the nearest neighbor method, can contribute from a portion of the waste supply requirement in the operation of the ITF. Fulfillment of the shortage of waste needs to be searched and analyzed again at the nearest sub-district location, so that the need for waste supply can be fulfilled properly. A limitation of this study is the need for an assessment of other supporting variables that significantly influence this research, which if examined more deeply can further refine this research in the future.

\section{References}

Abadi, C., Susanty, S., \& Adianto, H. (2014). Penentuan rute kendaraan distribusi produk roti menggunakan metode nearest neighbor dan metode sequential insertion (Determination of vehicle distribution for bread products using the nearest neighbor method and sequential insertion method). Jurnal Online Institut Teknologi Nasional Januari, 01(03), 2338-5081. Retrieved from https://ejurnal.itenas.ac.id/index.php/rekaintegra/article/view/267/519

Amponsah, S. K., \& Salhi, S. (2004). The investigation of a class of capacitated arc routing problems: The collection of garbage in developing countries. Waste Management, 24(7), 711-721. https://doi.org/10.1016/j.wasman.2004.01.008

Astriani, B. (2009). Organic and inorganic waste. Bogor Journal, 2(1), 77-84.

Azwar, A. (1990). Introduction to environmental health science. Jakarta: Yayasan Mutiara.

Bodin, L., Golden, B. M., Assad, A., \& Ball, M. (1983). Routing and scheduling of vehicles and crews: The state of the art. Computers and Operations Research, 10(2), 63-211. Retrieved from https://doi.org/10.1016/0305-0548(83)90030-8

Bräysy, O. (2001). Genetic algorithms for the vehicle routing problem with time windows. University of Vaasa, Finland. https://doi.org/10.1007/s10732-005-5431-6

Buhrkal, K., Larsen, A., \& Ropke, S. (2012). The Waste Collection Vehicle Routing Problem with Time Windows in a City Logistics Context. Procedia - Social and Behavioral Sciences, 39, 241-254. https://doi.org/10.1016/j.sbspro.2012.03.105

Calabrò, P. S. (2009). Greenhouse gases emission from municipal waste management: The role of separate collection. Waste Management, 29(7), 2178-2187. https://doi.org/10.1016/j.wasman.2009.02.011

Calabrò, P. S., Gori, M., \& Lubello, C. (2015). European trends in greenhouse gases emissions from integrated solid waste management. Environmental Technology (United Kingdom), 36(16), 2125-2137. https://doi.org/10.1080/09593330.2015.1022230

Chakrabarti, S., Majumder, A., \& Chakrabarti, S. (2009). Public-community participation in household waste management in India: An operational approach. Habitat International, 33(1), 125-130. https://doi.org/10.1016/j.habitatint.2008.05.009

Chandra, B. (2007). Pengantar kesehatan lingkungan (Introduction to environmental health). (P. Widyastuti, Ed.). Jakarta: EGC: Penerbit Buku Kedokteran.

Chi, Y., Dong, J., Tang, Y., Huang, Q., \& Ni, M. (2015). Life cycle assessment of municipal solid waste source-separated collection and integrated waste management systems in Hangzhou, China. Journal of Material Cycles and Waste Management, 17(4), 695-706. https://doi.org/10.1007/s10163-014-0300-8 
Cointreau-Levine, S. (1994). Private sector participation in municipal solid waste services in developing countries (1st ed.). Washington: World Bank. Retrieved from http://documents.worldbank.org/curated/en/325321468739287095/pdf/multi-page.pdf

Damanhuri, E. (2006). Teknologi dan Pengelolaan Sampah Kota di Indonesia (Technology and Management of Urban Waste in Indonesia). In Universitas Brawijaya Malang (Ed.), Workshop Nasional Biokonversi Limbah 11-12 April 2006 - Univ. Brawijaya Malang. Bandung. Retrieved from http://www.kuliah.ftsl.itb.ac.id/wpcontent/uploads/2008/08/unbrawbiokonv-110406.pdf

Das, S., \& Bhattacharyya, B. K. (2015). Optimization of municipal solid waste collection and transportation $\quad$ routes. Waste Management, 43, 9-18. https://doi.org/10.1016/j.wasman.2015.06.033

Fatharani, A. (2013). Penentuan Rute Pengambilan Sampah Menggunakan Metode Nearest Neighbour di PD. Kebersihan Kota Bandung untuk Kapasitas Kendaraan 10 m3 dengan pelayanan Bandung Selatan dan Bandung Timur (Determination of trash transport vehicle routes by using the nearest. Universitas Pasundan.

Fitria, L., Susanty, S., \& Suprayogi. (2009). Penentuan Rute Truk Pengumpulan dan Pengangkutan Sampah di Bandung (Determining truck routes for collecting and transporting garbage in Bandung). Jurnal Teknik Industri, 11(1), 51-60. Retrieved from http://jurnalindustri.petra.ac.id/index.php/ind/article/view/17101/17158

Hartanto, W. (2006). Kinerja pengelolaan sampah di kota gombong Kabupaten Kebumen (Performance of waste management in the city of Gembong, Kebumen Regency). Jurnal Tata Kelola Dan Daerah, 1, 24-29.

Ionescu, G., \& Stefani, P. (2014). Environmental assessment of waste transport and treatment: A case study. WIT Transactions on Ecology and the Environment, 180, 175-185. https://doi.org/10.2495/WM140151

Kholil, Eriyatno, Sutjahyo, S. H., \& Soekarto, S. H. (2009). Pengembangan Model Kelembagaan Pengelola Sampah Kota dengan Metode ISM (Development of the institutional model of city waste management in the ISM model). Journal Nasional Transdisiplin, Sosiologi, Komunikasi dan Ekologi Manusia), 2(4), 37-47.

Li, C.-Z., Zhang, Y., Liu, Z.-H., Meng, X., \& Du, J. (2014). Optimization of MSW collection routing system to reduce fuel consumption and pollutant emissions. Nature Environment and Pollution Technology, 13(1), 177-184. Retrieved from http://www.neptjournal.com/upload-images/NL-47-31-29-J13(1).pdf

Mardiani, U., Yossyafra, \& Gunawan, H. (2013). Efisiensi Rute Truk Pengangkutan Sampah Sistem Stationary Container di Kota Padang dengan Menggunakan Algoritma Nearest Neighbour (Efficiency of the garbage transport system stationary container system in Padang city by using the nearest neighbor algorith. TeknikA, 20(2), 35-44. Retrieved from http://ft.unand.ac.id/teknika/TeknikA Vol 20 No 2 Nov 2013-Uci Mardiani.pdf

Miller, G. T., \& Spoolman, S. E. (2016). Environmental Science (15th ed.). Boston: Cengage Learning. Retrieved from https://www.cengage.com/c/environmental-science-15e-miller Ministry of Energy and Mineral Resources of the Republic of Indonesia. (2015). Sampah Menjadi Energi (Waste to Energy). Jakarta. Retrieved from http://ebtke.esdm.go.id/download/index/646de099b4010a7500e7c5d8326f1694 
Nabavi-Pelesaraei, A., Bayat, R., Hosseinzadeh-Bandbafha, H., Afrasyabi, H., \& Berrada, A. (2017). Prognostication of energy use and environmental impacts for recycle system of municipal solid waste management. Journal of Cleaner Production, 148, 427-440. https://doi.org/10.1016/j.jclepro.2017.07.030

Nabavi-Pelesaraei, A., Bayat, R., Hosseinzadeh-Bandbafha, H., Afrasyabi, H., \& Chau, K. (2017). Modeling of energy consumption and environmental life cycle assessment for incineration and landfill systems of municipal solid waste management - A case study in Tehran Metropolis of Iran. Journal of Cleaner Production, 148, 427-440. https://doi.org/10.1016/j.jclepro.2017.01.172

Pop, P. C., Sitar, C. P., Zelina, I., Lupşe, V., \& Chira, C. (2011). Heuristic Algorithms for Solving the Generalized Vehicle Routing Problem P.C. International Journal of Computers Communications \& Control, 6(1), 158-165. https://doi.org/10.15837/ijccc.2011.1.2210

Rabbani, M., Sadri, S., \& Rafiei, H. (2014). Li. IMSS 2014 - 9th International Symposium on Intelligent Manufacturing and Service Systems, 203-212. Retrieved from http://safelir.tbzmed.ac.ir/article.aspx?id=5523

Rigamonti, L., Sterpi, I., \& Grosso, M. (2016). Integrated municipal waste management systems: An indicator to assess their environmental and economic sustainability. Ecological Indicators, 60, 1-7. https://doi.org/10.1016/j.ecolind.2015.06.022

Rimaityte, I., Denafas, G., Martuzevicius, D., \& Kavaliauskas, A. (2010). Energy and environmental indicators of municipal solid waste incineration: Toward selection of an optimal waste management system. Polish Journal of Environmental Studies, 19(5), 989998. Retrieved from http://www.pjoes.com/Energy-and-Environmental-Indicators-r-nofMunicipal-Solid-Waste-Incineration-r-ntoward,88474,0,2.html

Sahoo, S., Kim, S., Kim, B. I., Kraas, B., \& Popov, A. (2005). Routing optimization for Waste Management. Interfaces, 35(1), 24-36. https://doi.org/10.1287/inte.1040.0109

Surjandari, I., Hidayatno, A., \& Supriatna, A. (2009). Model dinamis pengelolaan sampah Untuk mengurangi beban penumpukan (Dynamic model of waste management to reduce burden). Jurnal Teknik Industri, 11(2), 134-147. Retrieved from http://puslit2.petra.ac.id/ejournal/index.php/ind/article/view/17683

Tchnobanoglous, T. (1993). Integrated soild waste management engineering principle and management issues. Singapore: Mc.Graw-Hill, Inc.

Tomić, T., \& Schneider, D. R. (2017). Municipal solid waste system analysis through energy consumption and return approach. Journal of Environmental Management, 203, 973-987. https://doi.org/10.1016/j.jenvman.2017.06.070

Utomo, S. W., Sutriyono, \& Rizal, R. (2014). Pengertian, Ruang Lingkup Ekologi dan Ekosistem (Definition, Ecology Scope and Ecosystem). Universitas Terbuka. Retrieved from http://repository.ut.ac.id/4305/1/BIOL4215-M1.pdf

Widomski, M. K., Gleń, P., \& Łagód, G. (2017). Sustainable landfilling as final step of municipal waste management system [Zrównoważone składowiska jako końcowy etap systemu gospodarki odpadami komunalnymi]. Problemy Ekorozwoju, 12(1), 147-155. Retrieved from http://ekorozwoj.pol.lublin.pl/no23/s.pdf 
Wy, J., Kim, B. I., \& Kim, S. (2013). The rollon-rolloff waste collection vehicle routing problem with time windows. European Journal of Operational Research, 224(3), 466476. https://doi.org/10.1016/j.ejor.2012.09.001

$\mathrm{Xu}, \mathrm{S} ., \mathrm{Li}, \mathrm{G} ., \mathrm{Ou}, \mathrm{H} ., \quad \& \mathrm{Wu}, \mathrm{W}$. (2015). Proceedings of China Modern Logistics Engineering (Vol. 286). Berlin: Springer-Verlag. https://doi.org/10.1007/978-3-66244674-4

Yogiesti, V., Hariyani, S., \& Sutikno, F. R. (2012). Pengelolaan Sampah Terpadu Berbasis Masyarakat Kota Kediri (Integrated waste management based on the Kediri city community). Jurnal Tata Kelola Dan Daerah, 2(2), 95-102. 